\title{
Detection of immunoglobulin heavy chain gene rearrangements in Hodgkin's disease using PCR
}

\author{
C A Angel, J H Pringle, L Primrose, I Lauder
}

\begin{abstract}
Aim-To detect clonal rearrangements of the immunoglobulin (Ig) heavy chain gene in Hodgkin's disease tissue using the polymerase chain reaction (PCR). Methods-DNA extracted from 36 samples of Hodgkin's disease was analysed using PCR and primers from conserved sequences in the variable $\left(V_{H}\right)$ and joining $\left(J_{H}\right)$ regions.

Results-Clonal rearrangement was detected only in one case. Evidence of clonal immunoglobulin gene rearrangement had been detected previously in this case using conventional Southern blot analysis.

Conclusions-The sensitivity of the two techniques is equivalent and clonal Ig heavy chain gene rearrangements are rare in Hodgkin's disease.
\end{abstract}

(F Clin Pathol 1993;46;940-942)

The use of antigen receptor gene rearrangement analysis in lymphoproliferative disease has now become widespread and has contributed greatly to our understanding of many such disorders. Since 1985 numerous publications have reported the use of these techniques in Hodgkin's disease, ${ }^{1}$ but to date there has been no consensus and little light has been shed on the cellular origin, pathogenesis, or nature of the disease. The antigen receptor genes are in germline configuration in more than $80 \%$ of cases studied, and many of the remaining cases show far from convincing evidence of true clonal Ig or T cell receptor (TCR) rearrangement. ${ }^{1}$

The putative malignant cell in Hodgkin's disease, the Reed-Sternberg cell, is seldom present in large numbers and often constitutes less than $5 \%$ of the total cell population in diseased tissues. Estimates vary, but antigen receptor gene rearrangement analysis by Southern blotting is thought to be capable of reliably detecting a clonal population if it constitutes $5 \%$ or more of the total cell population. ${ }^{23}$ It has therefore been suggested that the failure to detect antigen receptor gene rearrangements more frequently in Hodgkin's disease may be wholly or partly due to this relative lack of sensitivity. ${ }^{4-6}$

The polymerase chain reaction (PCR) is a highly sensitive molecular biological tool capable of amplifying and detecting one target sequence in at least $10^{6}$ cells. $^{7}$

\section{Methods}

Thirty six samples of Hodgkin's disease in which the configuration of the antigen receptor genes was known were studied. ${ }^{1}$ The histological subtypes are shown in table 1. All the samples were lymph nodes, received fresh in the laboratory, snap-frozen in isopentane, and stored in liquid nitrogen. Most samples were initial diagnostic biopsy specimens, although some were of recurrent disease and were taken after treatment. Three nonneoplastic lymph nodes and one hyperplastic tonsil were included as polyclonal controls. Placental DNA was used as a germline control, and two examples of known clonal B cell non-Hodgkin's lymphomas (B-NHL) were analysed as positive controls.

A sequence present in a region common to most $\mathrm{V}_{\mathrm{H}}$ segments, and another found in all $\mathrm{J}_{\mathrm{H}}$ segments were used. ${ }^{8}$ Primers to the major break point region of the BCL-2 putative oncogene, designated BCL-2A and BCL-2B, were also used. All sequences are shown in table 2 .

For polymerase chain reaction, DNA was prepared from fresh, frozen biopsy material by proteinase $\mathrm{K}$ digestion, phenol-chloroform extraction, and ethanol precipitation. Each sample was diluted to give a standard concentration of $0.5 \mu \mathrm{g} / 10 \mu \mathrm{l}$. PCR was carried out on an automatic temperature cycler (PerkinElmer Cetus) according to the method described by Saiki et al, ${ }^{9}$ with modifications. The reaction mixture contained $0.5 \mu \mathrm{g}$ DNA template, $45 \mathrm{mM}$ TRIS- $\mathrm{HCl}(\mathrm{pH} \mathrm{9.0)}, 11 \mathrm{mM}$ $\left(\mathrm{NH}_{4}\right) \mathrm{SO}_{4}, 4.5 \mathrm{mM} \mathrm{MgCl}, 50 \mu \mathrm{M}$ of each $\mathrm{dNTP}$, molecular biology grade bovine serum

Table 1 Histological subtypes of Hodgkin's disease cases

\begin{tabular}{lc}
\hline Histological subtypes & Number \\
\hline LPN & 2 \\
LPD & 1 \\
NS1 & 13 \\
NS2 & 14 \\
MC & 6 \\
Total & 36 \\
\hline
\end{tabular}

LPN = lymphocyte predominant nodular; $\mathrm{LPD}=$ lymphocyte predominant diffuse; NS1 = nodular sclerosing grade $1 ;$ NS 2 $=$ nodular sclerosing grade $2 ; \mathrm{MC}=$ mixed cellularity.

\begin{tabular}{ll} 
Table 2 & Primer sequences \\
\hline Primer & Sequence, 5'-3' \\
\hline $\mathrm{V}_{\mathrm{H}}$ & CTG TCG ACA CGG CCG TGT ATT ACT G \\
$\mathrm{J}_{\mathrm{H}}$ & AAC TGC AGA GGA GAC GGT GAC C \\
BCL-2A & CAC AGA CCC ACC CAG AGC CCT CCT \\
BCL-2B & AAT TCC CTT GTG AAA GAA ACG AAA \\
\hline
\end{tabular} \\ Pathology, The \\ Modical School, \\ S10 2UL \\ Pathology, University \\ of Leicester
}


albumin $110 \mu \mathrm{g} / \mathrm{ml}, 1 \mu \mathrm{M}$ of each oligonucleotide primer, and 2.5 units of Taq polymerase. The first PCR cycle consisted of denaturation of the sample at $98^{\circ} \mathrm{C}$ for 10 minutes, primer annealing at $65^{\circ} \mathrm{C}$ for 1 minute 30 seconds, and extension at $70^{\circ} \mathrm{C}$ for 2 minutes. Forty subsequent cycles consisted of $96^{\circ} \mathrm{C}$ for 1 minute 20 seconds, $62^{\circ} \mathrm{C}$ for 1 minute 30 seconds, and $70^{\circ} \mathrm{C}$ for 2 minutes. A final period of 10 minutes at $72^{\circ} \mathrm{C}$ was performed to complete the reaction.

After amplification the DNA from each reaction was ethanol precipitated and loaded on to a $3 \%$ Nusieve $1 \%$ Seakem agarose gel for electrophoretic resolution at 100 volts. Visualisation was performed by staining with $2 \mu \mathrm{g} / \mathrm{ml}$ ethidium bromide.

DNA from one of the known clonal B cell non-Hodgkin's lymphomas was serially diluted in tonsil DNA to determine the sensitivity of the reaction.

PCR experiments on cases of Hodgkin's disease were carried out in batched runs, each batch including placental DNA, tonsil DNA, and a no-template control. Each sample was amplified using the $\mathrm{V}_{\mathrm{H}}$ and $\mathrm{J}_{\mathrm{H}}$ primers to assess the immunoglobulin heavy chain gene. A second sample from each case was amplified using the primers BCL-2A and BCL-2B. This latter experiment was included only as an amplification control, and does not allow the status of the BCL-2 gene to be assessed.

\section{Results}

Only case 6 (fig 1) showed a definite clonal band, similar in intensity to that seen in the two examples of B cell NHL used as positive controls (fig 2). No other case showed definite evidence of clonal rearrangement, although numerous faint bands were seen in several tracks (fig 1). These were not interpreted as clonal bands for a variety of reasons. All were very faint compared with the clonal bands seen in the B-NHLs. Several faint bands of identical size were seen in numerous cases and controls and all were thought to be too large to represent the products of an amplified rearranged heavy chain gene, the expected size being between about 100 and 200 base pairs.

In the sensitivity assay (fig 3) a band was seen at all dilutions from $100 \%$ to $5 \%$, but beyond this the polyclonal smear obtained from the tonsil DNA obscured the clonal band. These findings agree with other results using these primers. ${ }^{8}$

Figure $1, P C R$ analysis of Hodgkin's disease cases 1-7. Results using $V_{H}$ and $\mathcal{F}_{H}$ primers shown in tracks labelled $B$. Results of control amplifications using BCL-2 primers shown in tracks labelled $A$. $P=$ placental $D N A, T=$ tonsil $D N A, N T=$ no template control. Size markers given in base pairs at right hand side derived from size standard, $\mathrm{Hae}$ from size standard, Hae
III endonuclease digested $\varphi X 174$.

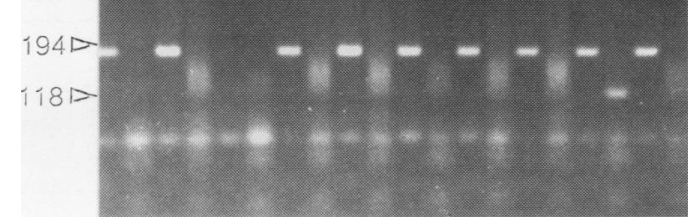

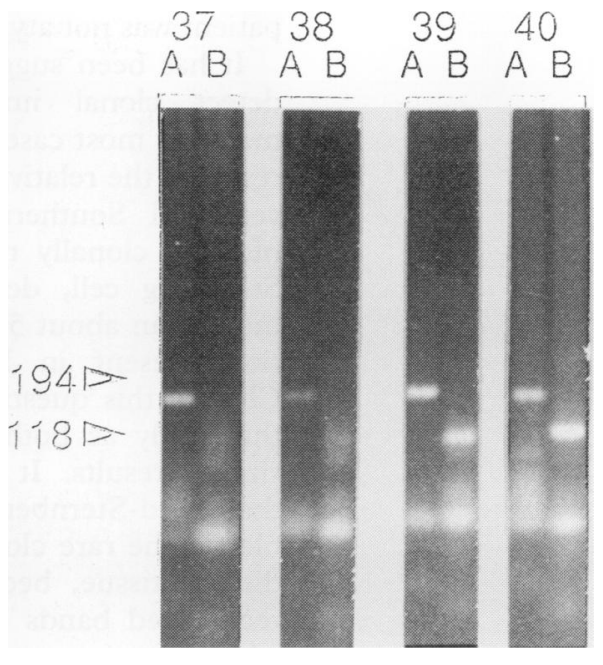

Figure $2 P C R$ analysis of two non-neoplastic lymph nodes (cases 37 and 38) and two B cell non-Hodgkin's lymphomas (cases 39 and 40).

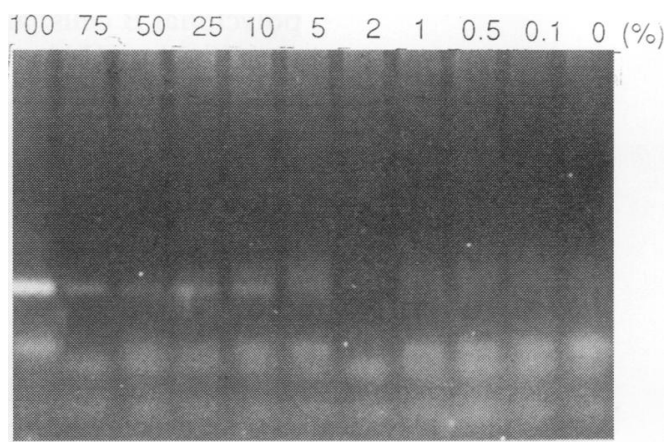

Figure 3 Sensitivity analysis of $P C R$ using $V_{H}$ and $\mathfrak{f}_{H}$ primers. DNA from case 40 (B-NHL) mixed with tonsil DNA. Percentage figures shown at top refer to percentage of tumour DNA in total template DNA added to the reaction mixture.

\section{Discussion}

Of 36 cases studied, only one sample of Hodgkin's disease showed clear evidence of clonal immunoglobulin heavy chain gene rearrangement using PCR and primers to the variable and joining regions of the gene. In a previous study, where conventional Southern blot analysis was used, this same case was the only sample to show convincing clonal Ig gene rearrangement. ${ }^{1}$ The conclusion of the previous study, that clonal rearrangement is a rare finding in unselected cases of Hodgkin's disease, is thus confirmed.

As previously discussed, ${ }^{1}$ there were no other unusual features in this rearranged case. Histologically, it was classified as nodular sclerosing (NS) Hodgkin's disease grade 1, and immunohistology showed no atypical features, except for a relatively large number of $B$ cells in the background population. $U p$ to about $40 \%$ of the lymphoid cells in the nodules were B cells, but there was no evidence of monotypia on cryostat section immunocytochemistry or on in situ hybridisation for immunoglobulin light chain mRNA. The Reed-Sternberg cells were phenotypically unremarkable, and the clinical course of the 
patient was not atypical.

It has been suggested that the inability to detect clonal immunoglobulin rearrangements in most cases of Hodgkin's disease is a result of the relative lack of sensitivity of conventional Southern blot analysis, ${ }^{4-6}$ as the putative clonally rearranged cell, the ReedSternberg cell, does not usually constitute more than about $5 \%$ of the total cell population present in Hodgkin's disease tissue. Clearly, this question remains unresolved by this study as both techniques seem to give similar results. It seems unlikely, however, that Reed-Sternberg cells are solely responsible for the rare clones detected in Hodgkin's disease tissue, because the intensity of the rearranged bands does not usually correlate with the percentage of Reed-Sternberg cells present. $^{1011}$

The relative lack of sensitivity of PCR in this context may seem surprising in view of the known high sensitivity of the technique in other situations. ${ }^{7}$ Most cases of Hodgkin's disease have a component of non-neoplastic, polyclonal B cells, all of which can give rise to amplifiable DNA templates, which can in turn compete with DNA derived from a monoclonal proliferation for the primers in the PCR reaction mixture. From the sensitivity analysis performed in this study, it would seem that when the monoclonal proliferation constitutes less than about $5 \%$ of the total cell proliferation, the monoclonal band becomes obscured by the polyclonal "smear" on a conventional agarose electrophoretic gel (fig 3). It may, however, be possible to resolve these bands using polyacrylamide gel electrophoresis.

Antigen receptor gene rearrangement analysis using conventional Southern blot technology may be of some use as an adjunct to the diagnosis of Hodgkin's disease, and when the differential diagnosis lies between Hodgkin's disease and NHL, absence of detectable rearrangements tends to confirm a diagnosis of Hodgkin's disease. PCR is capa- ble of giving a result within 24 hours of the biopsy, is cheaper and technically simpler than DNA blot analysis, and can be performed on very small amounts of relatively poor quality DNA, including DNA extracted from formalin fixed, paraffin wax embedded material. With the development of cocktails of primers capable of hybridising with all immunoglobulin heavy chain variable genes, PCR has the potential to replace conventional Southern blot analysis for diagnostic and research purposes in the study of lymphoproliferative disorders.

This work was supported by the Trent Regional Health Authority NHS Locally Organised Research Fund.

1 Angel CA, Pringle JH, Naylor J, West KP, Lauder I. Analysis of antigen receptor genes in Hodgkin's disease. f Clin Pathol 1993;46:337-40

2 Sklar J, Longtine J. The clinical significance of antigen receptor gene rearrangements in lymphoid neoplasia. Cancer Suppl 1992;70:1710-8.

3 Jacobson JO, Wilkes BM, Harris NL. Polyclonal rearrangement of T-cell antigen receptor genes in Hodgkin's disease: Implications for diagnosis. Mod Pathol 1991;4:172-7.

4 Weiss LM, Strickler JG, Hu E, Warnke RA, Sklar J. Immunoglobulin gene rearrangements in Hodgkin's disease. Hum Pathol 1986;17:1009-14.

5 Villa A, Cairo G, Pozzi MR, et al. Lack of TdT and immunoglobulin and T-cell receptor gene rearrangements in Hodgkin's disease. Int $\mathscr{f}$ Biol Markers 1987; 2:65-70.

6 Brinker MGL, Poppema S, Buys CHCM, Timens W, Osinga J, Visser L. Clonal immunoglobulin gene rearrangements in tissues involved by Hodgkin's disease. Blood 1987;70:186-91.

7 Young LS, Bevan IS, Johnson MA, et al. The polymerase chain reaction: a new epidemiological tool for investigating cervical human papillomavirus infection. Br Med $\mathcal{f}$ ing cervical human

8 McCarthy KP, Sloane JP, Wiedemann LM. Rapid method for distinguishing clonal from polyclonal B cell populations in surgical biopsy specimens. $\mathcal{F}$ Clin Pathol 1990;43:429-32

9 Saiki RK, Scharf S, Feloona F, et al. Enzymatic amplification of $\beta$-globin genomic sequences and restriction site analysis for diagnosis of sickle cell anaemia. Science 1985;230:1350-4.

10 Kodura PRK, Offit K, Filippa DA, Lieberman PH, Jhanwar SC. Cytogenetic and molecular genetic analysis of abnormal cells in Hodgkin's disease. Cancer Genet Cytogenet 1989;43:109-18.

11 Banks RE, Gledhill S, Ross FM, Krajewski A, Dewar AE, Weir-Thompson EM. Karyotypic abnormalities and immunoglobulin gene rearrangements in Hodgkin's disease. Cancer Genet Cytogenet 1991;51:103-11. 